\title{
Trends of World Cereals and Pulses Following the Human Populations
}

\author{
Shi Y Yang* \\ School of Agriculture Food and Wine, Waite Campus, Australia
}

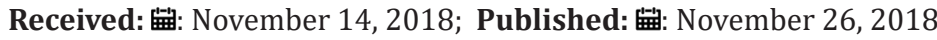

*Corresponding author: Shi Y Yang, School of Agriculture Food and Wine, Waite Campus, Waite Road, Urrbrae, SA 5064, Australia

\section{Mini Review}

Food is the first priority for the human beings. World food security is a serious and pressing contemporary issue [1]. Cereals (major rice, wheat, and maize, minor sorghum and millets) and pulses (major Chickpea, field pea, lupin, faba bean, lentils, etc) are basic elementary food sources. The plant protein is a key driver of agricultural market. Cereals and pulses are a sustainable and major source of protein, energy and fibre, which human beings particularly rely on. Pulses offer many benefits for nutrition, health and chronic disease prevention. As a result, there has been increased interest from food companies in using pulse for product formulations.
Cereal grains have been the critical component of human diet for thousands of years and have played very important role in shaping human civilization. Cereals are important staples critical to daily survival of billions of people. Over $50 \%$ of world daily caloric intake is derived directly from cereal grain consumption by the entire human population [2]. It was estimated that there are 1.45 billion vegetarians of necessity and another 75 million of choice, thus approximately $21.8 \%$ of the world's population rely on plant protein as their major protein source [3]. Pulses are a major source of plant protein for vegetarian people.

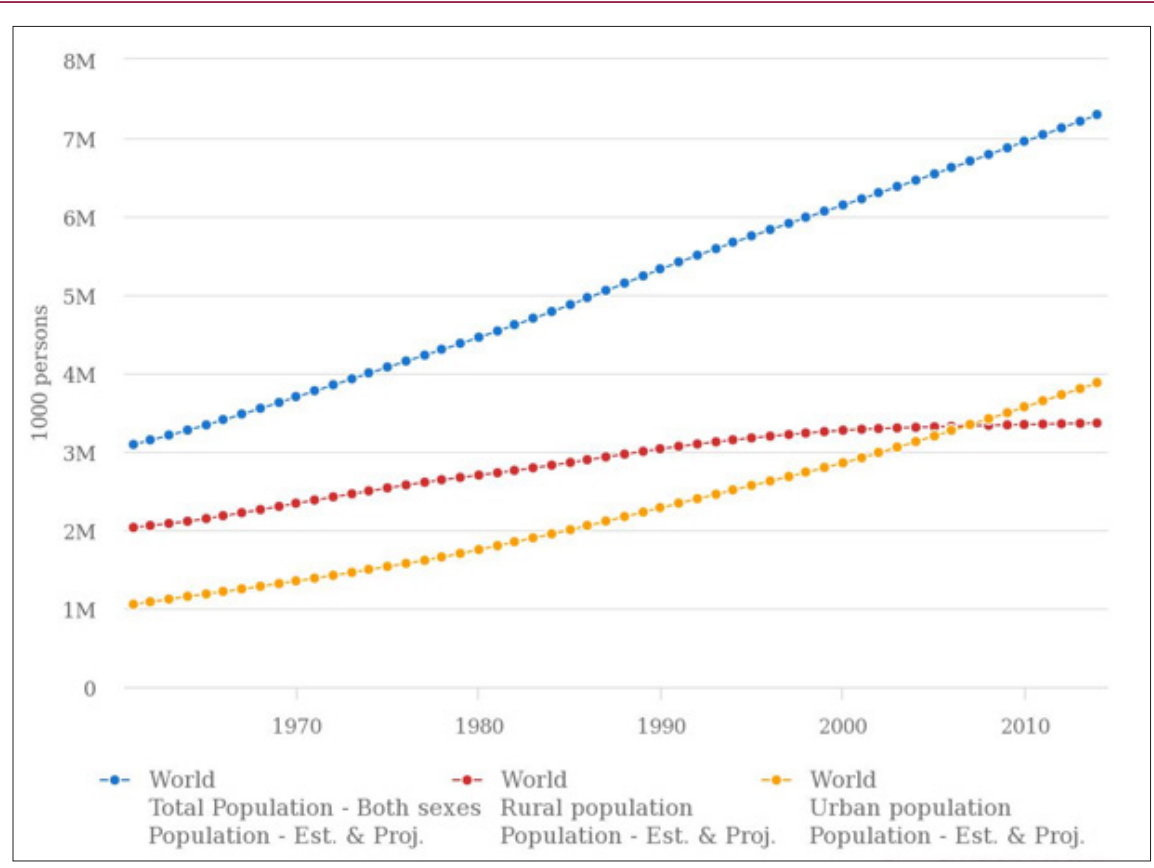

Figure 1: World Total population from 1961 to 2016.

Pulses have a major role in sustainable agricultural systems. They produce their own fertiliser by fixing nitrogen from the air. This not only has a direct benefit to the cropping system, but also has flow-on benefits through overall energy efficiency compared to other crops as seventy percent of non-renewable energy used in cropping systems is attributable to fertilisers. Plant derived protein is far more water efficient than animal protein: 43 gallons of water is required to produce one pound of pulses, 469 gallons 
for one pound of chicken, 756 gallons for one pound of pig and 1,857 gallons of water is required for one pound of beef [4]. The world grew significantly in terms of both population and economic development in the period 1961-2016. As a result of the industrial revolution, lifespan and survival rate improved, and the world's population more than doubled from about 2.5 billion in 1961 to 6.1 billion in 2000, and then up to 7.2 billion in 2016, nearly triple in these 56 years [5] (Figure 1, FAOSTAT). Interestingly, during this period, the production of the grains, cereals was tripled from 877 million tonnes in 1961 to 2.8 billion tonnes in 2016 and pulses was also doubled from 40.8 million tonnes in 1961 to 81.8 million tonnes in 2016. FAO projections are that the human population will be up to 9.3 billion in 2050 .

This is another $30 \%$ increase in the populations in the next three decades. The booming population will put a great pressure on the food and grain system. According to above pattern of human population's growth with the production of cereals and pulses, in order to meet the demand from the increased population it will be required that production of the fundamentally basic foods of grains increase another $30 \%$ in the next 30 years to feed the growing peoples. The expansion in area and increase in productivity of cereals and pulses have contrasted in the past 56 years [5] (Figure 2, FAOSTAT). The world's total area of cereals harvested in 1961 was about 648 million ha, and production was 877 million tonnes with an average yield of about $1.35 \mathrm{tha}^{-1}$. In 2016, the world's total cereals harvested area was about 718 million ha, an increase of $10.8 \%$ in 56 years. However, production and yield tripled in this period with production of 2.8 billion tonnes and average yield about $3.97 \mathrm{t} \mathrm{ha}^{-1}$ in 2016. These increases in production could be attributed to improved yield as a consequence of the development and application of new technologies such as availability of higher yield of hybrid varieties and application of better agronomy technologies.

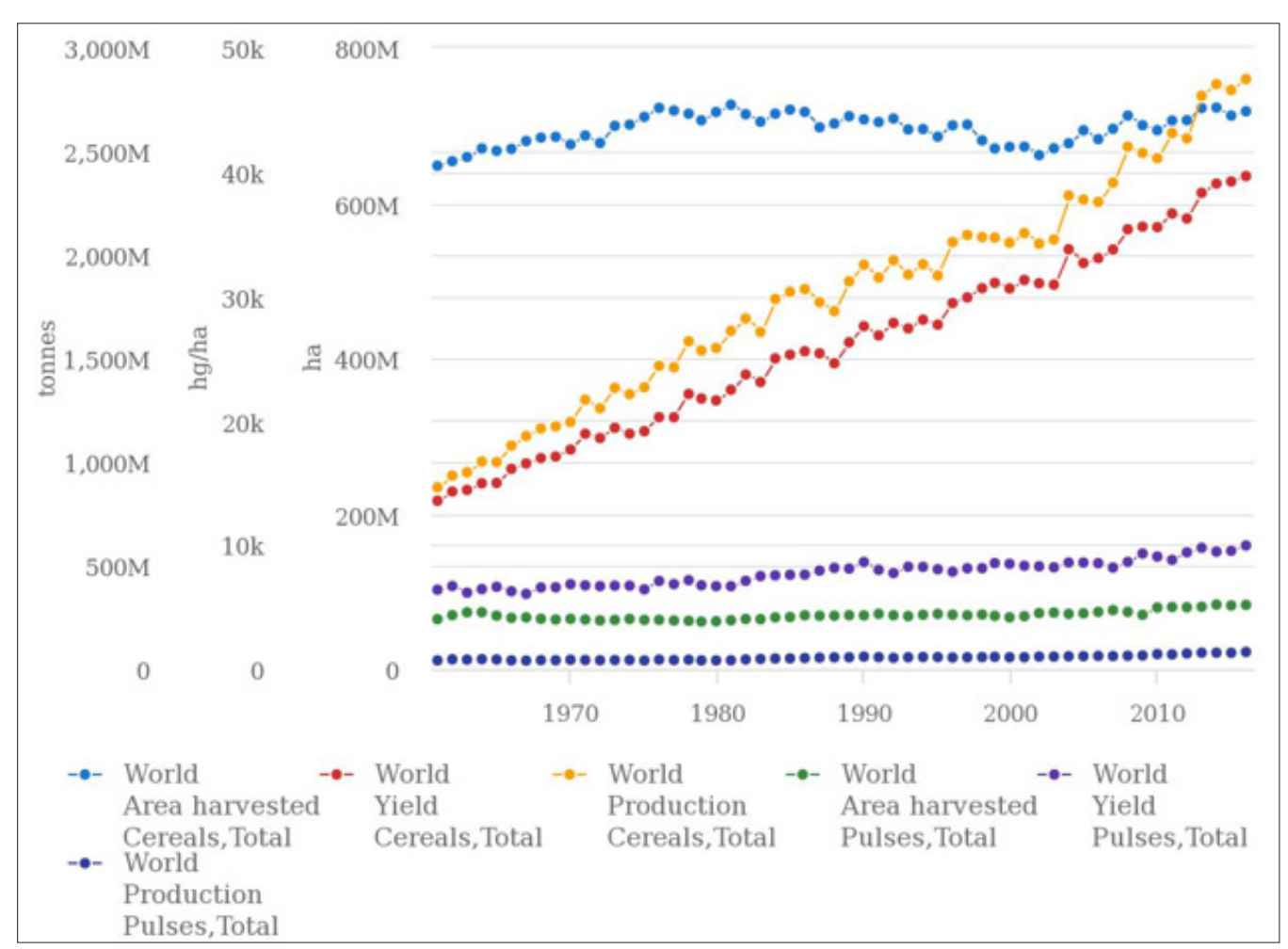

Figure 2: World Total Area and Production of Cereals and Pulses from 1961 to 2016.

The total area of pulses harvested in 1961 was 64 million and increased to 82.4 million ha in 2016. This represents an increase of $28.8 \%$ which is more than double the percentage increase for cereals and indicates that there is increased interest in growing pulses. Global production of pulses doubled from 40.8 million tonnes in 1961, to 81.8 million tonnes in 2016. The yield of pulses was about $0.64 \mathrm{t} \mathrm{ha}^{-1}$ in 1961 , but increased to $1.0 \mathrm{t} \mathrm{ha}^{-1}$ in 2016 , an increase of just $55.8 \%$ compared to cereals where yield was tripled in the same period. It is highly likely cultivation of pulses will continue to increase as people understand more about the value and contribution to health of pulses, while the relatively low increase in yield of pulses, compared to cereals, suggests that there is significant potential to improve the yield of pulses. Beside the major crops of cereals and pulses, there are some minor cereal and pulse crops classified as nes (not elsewhere specified) [5]. These crops include: cereals nes - Including inter alia: canagua or coaihua (Chenopodium pallidicaule); quihuicha or Inca wheat (Amaranthus caudatus); adlay or Job's tears (Coix lacryma-jobi); wild rice (Zizania aquatica) and pulses nes - Including inter alia: lablab or hyacinth bean (Dolichos spp.); jack or sword bean (Canavalia spp.); winged bean (Psophocarpus tetragonolobus); guar bean (Cyamopsis tetragonoloba); velvet bean (Stizolobium spp.); yam bean (Pachyrrhizus erosus); Vigna spp. The data is in Figure 3 (FAOSTAT). 


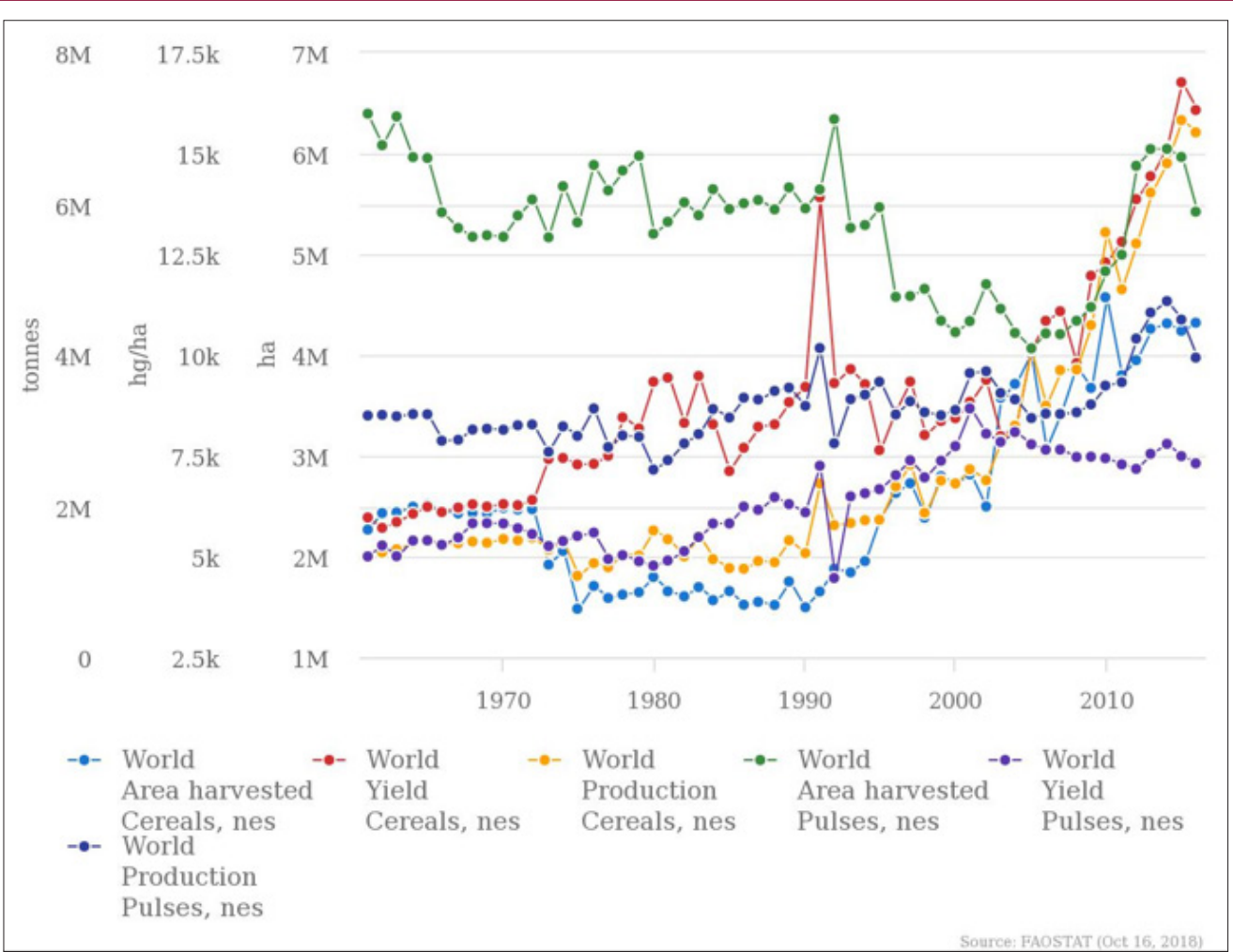

Figure 3: World Total Area and Production of Cereals and Pulses (nes) from 1961 to 2016.

The world cereals harvested area (nes) has three stages of development during the last 56 years. The world cereals harvested area was approximately 2.2 million ha in 1961, and production was about 1.35 million tonnes, it dropped to 1.48 million ha in 1975 , with production of 1.08 million tonnes. After that, it gradually recovered. From 1990 to 2016, the cereals (nes) was flying growth in both area and production. Harvested area from 1.5 million hectares to 4.32 million hectares, which was $188 \%$ increase. The world pulse (nes) development trend is different to cereals (nes) during these nearly six decades. Its harvested area (nes) was 6.5 million ha in 1961 but dropped slowly to 5.17 million hectares in 1968. After that, it fluctuated between 5.17 million ha in 1973 and 5.98 million ha in 1980 and remained constant from 1980 to 1991. The area continued to decrease and reached the minimum area of 4.1 million ha in 2005 but has subsequently recovered and reached 6.4 million ha in 2013. During these six decades, the total harvested area of these minor pulses was between 4 and 6.5 million ha with production from 2 to 3 million tonnes.

\section{Summary}

In general, there has been an increase in demand for food with growth of the human population. The major staple food sources of cereals and pulses have grown with similar trends to the human population. During last six decades, the human population are tripled. The grains included the cereals and pulses are doubled or tripled in production during those periods. As the population is projected to grow to 9.3 billion in 2050 (FAO projected and estimated) which is another approximately $30 \%$ of growth, there is great pressure on food for another $30 \%$ of growth, as well as the great demand for grains of cereals and pulses. In order to secure these food sources, every country needs to pay more attention to the agriculture industry development.

The pulses total harvested area increased $28.8 \%$ for the period 1961 - 2016, which in percentage terms is twice the increase for cereals. Production of pulses doubled in this period and it is highly likely to continue to increase as people understand more about the value and health benefits of the pulses as food. It is said the cereals yield has already achieved a certain ceiling or plateau [1], which has tripled during last half century. The Agriculture sector need to discover alternative ways to increase the productivity. The yield of pulses has increased just $55.8 \%$ in nearly six decades, compared to cereals yields which have tripled in the same period. Hence this is great potential to develop higher yields of pulses crops, but it will require more attention and more input from the world to make this happen.

\section{Acknowledgement}

It's highly appreciated that Dr Jeffrey Paull of University of Adelaide has provided valuable commons and edited this draft.

\section{References}

1. Tony Fischer, Derek Byerlee, Greg Edmeades (2014) Crop yields and global food security: will yield increase continue to feed the world? Australian Centre for International Agricultural Research (ACIAR) Monograph MN 158: 3.

2. Vegetarianism.

3. Joseph M Awika (2011) Major Cereal Grains Production and Use around the World. American Chemical Society Publications 1: 1-13.

4. Hoekstra, Chapagain (2010) Globalization of water, U of Twente, Waterfootprint.org National Geographic.

5. http://www.fao.org/faostat18 
ISSN: 2574-1241

DOI: 10.26717/BJSTR.2018.11.002098

Shi Y Yang. Biomed J Sci \& Tech Res

(C) (P) This work is licensed under Creative

Submission Link: https://biomedres.us/submit-manuscript.php

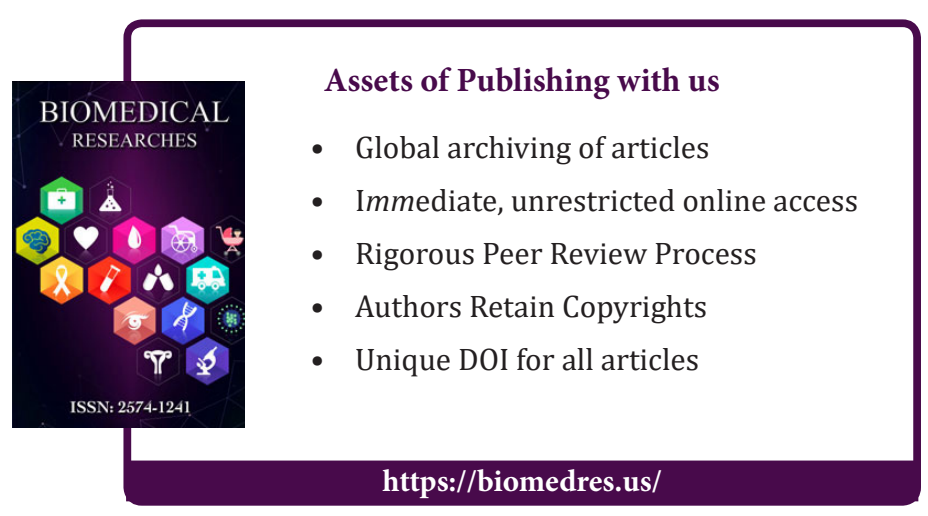

